\title{
PENGARUH DIVIDEN INISIASI DAN DIVIDEN OMISI TERHADAP RETURN SAHAM DI BURSA EFEK INDONESIA
}

\author{
Azizah Ayu Sielvia \\ Universitas Islam Indonesia Yogyakarta \\ e-mail:azizahsielvia@yahoo.co.id
}

\begin{abstract}
The objective of this study is to determine the effect of dividend initiations and dividend omission of stock returns in Indonesia Stock Exchange (BEI). Variables in this study consist of dividends, dividend announcements, and a significant stock return on dividend announcement reflected the presence of abnormal return during the event period. This study employs the company's shares listed on Indonesia Stock Exchange and are actively traded. Samples used as many as 50 companies, where 37 companies as a dividend initiation and 13 companies as a dividend omission. The sample selection was done by purposive sampling method that is research based on certain criteria. Results of analysis testing the effect of the abnormal return of dividend announcements indicate a significant influence. Announcements of dividend initiations have significant positive influence, while the announcements of dividend omissions have significant negative market reaction. That means the announcement of dividend initiations have a signal or a specific information content that causes the market to react more than normal state of the information, while the announcement of dividend omissions affect investors to remove their stock price moves down or there is a significant abnormal return.
\end{abstract}

Keywords: dividend initiation, dividend omission, dividend announcement, stock return

\section{PENDAHULUAN}

Investor yang menginvestasikan dananya di pasar modal bertujuan untuk memperoleh imbalan atau pendapatan dari dana yang diinvestasikan tersebut baik berupa dividen atau capital gain. Dividen ini merupakan bagian keuntungan perusahaan yang dibagikan kepada para pemegang saham sedangkan capital gain merupakan bagian keuntungan perusahaan yang akan ditahan untuk reinvestasi (Husnan, 2005). Sehingga perubahan kebijakan dividen sekecil apapun dianggap mampu mempengaruhi reaksi investor dan akhirnya dapat mempengaruhi harga saham.

Perusahaan melakukan perubahan kebijakan dividen dengan berbagai alasan, misalnya kebijakan pembayaran dividen pertama kali setelah beberapa tahun tidak membayar dividen (dividend initiation) dilakukan untuk memberi informasi bagi investor akan prospek laba perusahaan yang lebih baik untuk saat ini dan dimasa depan. Sedangkan kebijakan memotong ataupun menghapus pembayaran dividen (dividend cut/omissions) dilakukan perusahaan karena perusahaan membutuhkan dana untuk membiayai pertumbuhan perusahaan. Oleh karena itu, jika pengumuman perubahan kebijakan dividen yang tidak diantisipasi ini merupakan petunjuk bagi pasar mengenai perubahan laba yang diperoleh perusahaan maka kandungan informasi ini dapat memicu pergerakan harga saham naik atau turun.

Dividen yang dibagikan perusahaan kepada investor sering kali digunakan sebagai alat untuk menilai prospek perusahaan dimasa yang akan datang dan pengaruh nya terhadap nilai perusahaan. Dividen inisiasi adalah pembayaran dividen 
tunai pertama kalinya setelah minimal dua kali berturut-turut tidak membayar dividen tunai selama beberapa periode. Perusahaan yang menetapkan kebijakan membayar dividen pertama kali (dividend initiations) merupakan sinyal dan pasar akan bereaksi positif. Perusahaan tidak akan membagikan dividen apabila prospek pertumbuhan laba dan arus kas masa depan kurang baik. Dividen omisi adalah penghapusan dividen tunai pertama kalinya setelah beberapa kali secara berturut-turut membayar dividen tunai. Kebijakan perusahaan untuk menghapus pembayaran dividen pertama kalinya (dividend omissions) merupakan sinyal yang kurang baik sehingga pasar akan bereaksi negatif.

Pengumuman terhadap dividend omissions tidak semuanya direspon dengan negatif, pada umumnya ketika perusahaan tidak membayar dividen dianggap prospek perusahaan dimasa yang akan datang kurang bagus. Perusahaan yang menghapus atau tidak membayar dividen belum tentu merupakan perusahaan yang berkualitas. Sebab ada kemungkinan perusahaan yang menunda pembayaran dividennya laba yang diperoleh untuk membiayai investasinya. Oleh karena itu, tujuan yang hendak dicapai dalam penelitian ini adalah untuk mengetahui pengaruh dividen inisiasi dan dividen omisi terhadap return di Bursa Efek Indonesia.

\section{KAJIAN TEORI}

Menurut kamus besar bahasa Indonesia dividen merupakan bagian laba atau pendapatan yang besarnya ditetapkan oleh direksi dan disahkan oleh rapat pemegang saham untuk dibagikan kepada pemegang saham. Dengan kata lain dividen merupakan bagian laba pemegang saham perseroan terbatas yang nilainya sebanding dengan jumlah lembar saham yang dimiliki. Jumlah dan waktu pembayaran ditentukan oleh para pemegang saham dan direksi pada saat Rapat Umum Pemegang Saham (RUPS). Pembayaran ini biasanya diumumkan setiap kuartal oleh dewan komisaris dan dibayarkan ke pemegang saham pada tanggal yang telah ditentukan yang disebut tanggal pencatatan (date of record). Dalam suatu pembagian dividen ada empat tanggal yang perlu diperhatikan, yaitu:

1. Tanggal pengumuman

2. Tanggal pendaftaran

3. Tanggal ex-dividen

4. Tanggal pembayaran dividen

Dalam keputusan pembagian dividen, perusahaan perlu mempertimbangkan kelangsungan hidup dan pertumbuhan perusahaan. Dengan demikian laba tidak seluruhnya dibagikan kedalam bentuk dividen namun perlu disisihkan untuk diinvestasikan kembali.

Ada dua pendapat mengenai relevansi kebijakan dividen, yaitu (1) pendapat yang menyatakan bahwa dividen tidak relevan, dan (2) pendapat yang menyatakan bahwa dividen adalah relevan dalam kaitannya dengan kemakmuran pemegang saham.

\section{Pendapat tentang ketidakrelevanan dividen (Irrelevant Theory)}

Pendapat ini dikemukakan oleh Modigliani dan Miller (1961). Modigliani dan Miller (MM) memberikan argumentasi bahwa pembagian laba dalam bentuk dividen tidak relevan dengan nilai perusahaan. MM menyatakan bahwa, dividend payout ratio (DPR) hanya merupakan bagian kecil dari keputusan pendanaan perusahaan. DPR tidak mempengaruhi kekayaan pemegang saham. MM beragumentasi bahwa nilai perusahaan ditentukan tersendiri oleh kemampuan aktiva perusahaan untuk menghasilkan laba atau kebijakan investasi. Jadi dalam rangka membagi laba perusahaan menjadi dividen dan laba yang ditahan tidak mempengaruhi 
nilai perusahaan. Dalam hal ini, MM berasumsi bahwa adanya pasar modal sempurna dimana tidak ada biaya transaksi, biaya pengambangan (floatation cost) dan tidak ada pajak.

\section{Pendapat tentang relevansi dividen (Relevant Theory)}

Pendapat ini mencoba membantah pendapat ketidakrelevanan pembayaran dividen. Sejumlah argumentasi diajukan untuk mendukung posisi yang kontradiksi yaitu bahwa dividen adalah relevan untuk kondisi yang tidak pasti. Pendapat ini terutama ditujukan untuk keadaan yang penuh ketidakpastian. Ada beberapa teori yang dapat digunakan oleh perusahaan untuk menerangkan bahwa dividen yang dibayarkan digunakan sebagai isyarat mengenai prospek return di masa yang akan datang. Dalam penelitian ini digunakan dividend signaling theory sebagai kerangka teorinya karena teori ini relevan dengan tujuan penelitian yaitu untuk membuktikan bahwa pengumuman perubahan pembayaran dividen mengandung informasi (Martono dan Harjito, 2007).

Dividend signaling theory berdasarkan pada asumsi bahwa dividen diperlukan untuk memberikan informasi positif dari manajer yang mempunyai informasi lengkap tentang kondisi perusahaan yang sesungguhnya kepada investor yang miskin informasi tentang perusahaan yang sesungguhnya. Fenomena seperti ini terjadi karena adanya asymmetric information antara manajer dengan investor. Pengumuman dividen sebagai alat untuk mengirimkan isyarat yang nyata kepada pasar mengenai hasil kerja perusahaan di masa kini dan di masa yang akan datang adalah merupakan cara yang tepat meskipun mahal tapi sangat berarti. Setelah menerima isyarat melalui pengumuman dividen maka pasar akan bereaksi terhadap pengumuman perubahan dividen yang akan dibayarkan sehingga bisa dikatakan pasar menangkap informasi tentang prospek perusahaan yang terkandung dalam pengumuman tersebut.

Pendapat umum dalam literatur keuangan baik empiris maupun teoritis menyatakan bahwa pada umumnya, dividen inisiasi memiliki positive impact on firm value. Beberapa peneliti berpendapat bahwa pengumuman inisiasi secara tidak terantisipasi memberikan optimistic signal mengenai kinerja prusahaan di masa depan. Asquith dan Mullins (1983) secara konseptual menyatakan bahwa abnormal return yang dihubungkan dengan inisiasi dividen dapat dibagi menjadi dua komponen, a yield effect dan an initiation effect. Efek inisiasi merefleksikan nilai yang dihasilkan dari pembayaran dividen periode berikutnya dan didapatkannya manfaat dengan adanya program inisiasi dividen. The yield effect meliputi perubahan nilai yang dihasilkan dari besarnya initial dividend dan menangkap information content atas pembayaran dividen tersebut.

Sedangkan reaksi pasar terhadap dividen omisi secara umum negatif karena pemotongan dan penghapusan dividen dianggap sebagai bad news oleh investor. Beberapa peneliti menemukan bukti empiris bahwa pemotongan dan penghapusan dividen direspon negatif oleh pasar dan besarnya reaksi tersebut lebih besar dibanding reaksi pasar terhadap peningkatan dividen. Alasan yang diajukan terhadap fenomena ini adalah karena pengurangan dividen dianggap lebih banyak mengandung informasi (Caecilia, 2002).

Gosh dan Woolridge (1988) melakukan penelitian mengenai reaksi pasar terhadap dividend cut/omission serta menggunakan model regresi berganda untuk mengetahui pengaruh variabel seperti presentase perubahan dividen, ukuran perusahaan, kinerja saham sebelumnya, risiko pengumuman simultan earning, dan stock dividend yang dikeluarkan serentak 
dengan pengumuman dividen. Menemukan bukti empiris bahwa pasar bereaksi negatif terhadap pengumuman dividen omisi dan dipengaruhi oleh ukuran perusahaan, presentase perubahan dividen serta kinerja saham sebelum pengumuman.

Healy dan Palepu (1988) mendukung hipotesis kandungan informasi dividen yang diusulkan oleh Modigliani-Miller. Healy dan Palepu (1988) melakukan penelitian dengan menguji sampel sebanyak 131 perusahaan yang mebayar dividen untuk pertama kalinya dan 172 perusahaan yang menghapus dividen pertama kalinya. Periode penelitian yang dugunakan antara tahun 1969-1988. Hasil penelitian yang mereka lakukan menunjukkan bahwa kebijakan perusahaan untuk membayar atau menghapus dividen pertama kalinya ditanggapi oleh pasar sebagai ramalan perusahaan mengenai peningkatan dan penurunan laba dimasa yang akan datang.

Penelitian mengenai reaksi pasar terhadap pengumuman perubahan pembayaran dividen di Indonesia antara lain dilakukan oleh Kartini (2001). Sampel yang digunakan sebanyak 50 perusahaan periode1993-1996. Hasil pengujian terhadap hipotesis kandungan informasi dividen baik yang meningkat atau menurun menunjukkan bahwa pemegang saham bereaksi negatif terhadap pengumuman perubahan pembayaran dividen. Hal ini menunjukkan bahwa temuan penelitian ini mendukung hipotesis kandungan informasi dividen yang menyatakan bahwa pengumuman dividen mengandung informasi yang berguna bagi pemegang saham.

Mulyati (2003) melakukan penelitian reaksi harga saham terhadap perubahan dividen tunai dan dividen yield di BEI. Sampel penelitian sebanyak 52 perusahaan yang terdiri dari 27 perusahaan yang membayar dividen naik dan 25 perusahaan yang membayar dividen turun. Periode pengamatan pada penelitian yang digunakan adalah tahun 1995-1996. Hasil penelitian menunjukkan bahwa reaksi saham positif terhadap kenaikan dividen yang dibayarkan pada hari ke 5 sebelum pengumuman, sedangkan reaksi harga saham negatif terhadap penurunan dividen yang dibayarkan pada hari ke 5 setelah pengumuman dividen. Hal ini menunjukkan bahwa pengumuman dividen mengandung sutau informasi.

Puspitasari dan Witono (2004) melakukan pengujian pengaruh pengumuman dividen tunai ditinjau dari kenaikan dan penurunan dividen terhadap variabilitas tungkat keuntungan saham di Bursa Efek Indonesia. Penelitian ini hanya dilakukan pada perusahaan yang melakukan pengumuman dividen tunai dari tahun 20002002. Kesimpulan yang diperoleh bahwa dalam penelitian tersebut secara keseluruhan tidak terdapat information content dalam pengumuman dividen. Tidak terdapat perbedaan yang signifikan antara rata-rata variabilitas tingkat keuntungan saham sebelum dan sesudah pengumuman.

Lebih lanjut penelitian mengenai reaksi pasar terhadap inisiasi dividen dan omisi dividen di BEI antara lain dilakukan oleh Setyowuri (2005). Penelitian dilakukan dengan mengguankan sampel perusahaan yang membayar dividen pertama kalinya dan sampel perusahaan yang menghapus dividen pertama kalinya. Hasil penelitian sebelum dan sesudah koreksi beta menunjukkan pasar bereaksi terhadap pengumuman pembayaran dividen tunai pertama kalinya, hal ini ditunjukkan dengan adanya abnormal return yang cukup signifikan. Pengujian terhadap pengumuman penghapusan dividen pertama kalinya baik sebelum dan sesudah koreksi beta menunjukkan pasar tidak bereaksi terhadap pengumuman dividen.

Dewantoro (2005) melakukan analisis ketepatan reaksi pasar terhadap perusahaan yang mengumumkan dividend initiations di BEI. Sampel penelitian adalah 
perusahaan yang melakukan pengumuman inisiasi dari tahun 1997-2003 sebanyak 24 perusahaan. Hasil penelitian tidak menunjukkan adanya perbedaan yang signifikan antara mean abnormal return sebelum dan sesudah peristiwa. Sehingga hipotesis yang menyatakan bahwa terdapat kandungan informasi dalam pengumuman inisiasi ditolak.

Berdasarkan uraian dan beberapa tinjauan penelitian terdahulu di atas, maka hipotesis yang diajukan dalam penelitian ini adalah sebagai berikut:

H1: Pengumuman inisiasi dividen berpengaruh positif yang signifikan terhadap nilai abnormal return.

H2: Pengumuman omisi dividen berpengaruh negatif yang signifikan terhadap nilai abnormal return.

\section{METODE PENELITIAN}

Penentuan sampel adalah dengan purposive sampling method. Sampel yang dipilih adalah semua perusahaan yang melakukan inisiasi dan omisi dividen mulai tahun 2004-2008. Kriteria pemilihan sampel perusahaan yang membayar dividen pertama kalinya adalah sebagai berikut:

1) Dividen inisiasi adalah pembayaran dividen tunai pertama kalinya setelah minimal 2 kali berturut-turut tidak membayar dividen tunai selama periode 2004 - 2008.

2) Perusahaan yang dijadikan sampel adalah perusahaan yang melakukan pembayaran dividen untuk pertama kalinya dalam waktu minimal 2 tahun setelah IPO.

3) Perusahaan yang dijadikan sampel adalah perusahaan yang memiliki kebijakan pembayaran dividen tunai setahun sekali selama periode pengamatan.

4) Perusahaan yang dijadikan sampel adalah perusahaan yang tidak melakukan corporate action seperti stock splits, righ issue, merger, akuisisi atau restrukturisasi selama periode kejadian yaitu 21 hari (10 hari sebelum kejadian tanggal pengumuman, sehari pada tanggal pengumuman, dan 10 hari setelah tanggal pengumuman).

Adapun kriteria pemilihan sampel perusahaan yang menghapus dividen pertama kalinya adalah sebagai berikut:

1) Dividen Omisi adalah penghapusan dividen tunai pertama kalinya setelah periode pengamatan. Perusahaan tersebut harus sudah terdaftar di Bursa Efek Indonesia selama 2 tahun atau lebih dan biasanya membayar dividen tunai secara rutin dalam jumlah tetap, meningkat dan menurun namun 2004 2008 melakukan penghapusan dividen pertama kalinya.

2) Perusahaan yang dijadikan sampel adalah perusahaan yang memilki kebijakan pembayaran dividen tunai setahun sekali selama periode pengamatan.

3) Perusahaan yang dijadikan sampel adalah perusahaan yang tidak melakukan corporate action seperti stock splits, right issue, merger, akuisisi, atau restrukturisasi sebelum periode kejadian yaitu 21 hari (10 hari sebelum tanggal pengumuman, sehari pada tanggal pengumuman dan 10 hari setelah tanggal pengumuman omisi dividen).

Data yang digunakan dalam penelitian ini adalah data sekunder yang meliputi 37 perusahaan yang merupakan dividen inisiasi dan 13 perusahaan dividen omisi. Metode pengumpulan data menggunakan metode studi pustaka, yaitu dengan mengumpulkan data-data literatur yang berhubungan dengan obyek penelitian dan sumber lain yang relevan. Data ini diperoleh dari pojok Bursa Efek Indonesia Fakultas Ekonomi Universitas Islam 
Indonesia, ICMD, INDOFINANZ.com, dan PPM Universitas Gadjah Mada.

Pengujian reaksi pasar terhadap pengumuman dividen dalam penelitian ini menggunakan event study. Event study merupakan studi yang mempelajari reaksi pasar terhadap suatu peristiwa (event) yang informasinya dipublikasikan sebagai suatu pengumuman. Reaksi pasar diukur dengan menggunakan abnormal return, jika suatu pengumuman yang mempunyai kandungan informasi akan memberikan abnormal return.

Penelitian ini menggunakan event period selama 21 hari, 10 hari sebelum peristiwa, 1 hari pada saat perstiwa, dan 10 hari setelah peristiwa terjadi. Dipilih 21 hari karena pengumuman dividen merupakan peristiwa yang bersifat rutin atau setiap tahun terjadi sehingga peristiwa tersebut kemungkinan sudah diantisipasi oleh investor. Investor dapat bereaksi dengan cepat disebabkan oleh nilai ekonomis dari pengumuman dividen dapat dinilai dengan cepat (Jogiyanto, 2005).

Tanggal yang dianggap sebagai event pengumuman inisiasi dividen adalah pada saat pengumuman pembayaran dividen oleh emiten. Sedangkan tanggal yang dianggap sebagai event pengumuman omisi dividen adalah tanggal RUPS yang dilaporkan ke BEI dan sudah dipilih rapat yang tidak membahas stock splits, right issue dan divestasi, dan tanggal ini ditetapkan sebagai $\mathrm{t}_{\mathrm{o}}$. Periode penelitian digambarkan sebagai berikut:

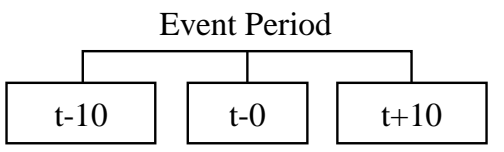

Periode estimasi yang digunakan dalam penelitian ini adalah 100 hari. Periode penelitian ini ditetapkan sejak t-110 sampai t-11. periode estimasi ini selanjutnya akan digunakan untuk mengestimasi return saham yang digunakan. Model yang digunakan dalam penelitian ini adalah market model yang digunakan Brown dan Warner dalam event study (Jogiyanto, 2003) selanjutnya dihitung expected return untuk event period. Abnormal return diperoleh dari selisih antara return saham dengan expected return. Pengumuman dividen kemudian diuji dengan menggunakan uji t. Langkahlangkah pengolahan data dalam periode estimasi adalah sebagai berikut:

1) Menghitung Return saham harian $\left(\mathrm{R}_{\mathrm{it}}\right)$ individual selama hari pengamatan:

$$
\begin{aligned}
\mathrm{R}_{\mathrm{it}}= & \frac{\mathrm{P}_{\mathrm{it}}-\mathrm{P}_{\mathrm{it}-1}}{\mathrm{P}_{\mathrm{it}-1}} \\
\mathrm{Di}_{\mathrm{it}}= & \text { Return saham harian saham } \mathrm{i} \\
& \text { pada hari } \mathrm{t} \\
\mathrm{R}_{\mathrm{it}}= & \text { Harga saham harian saham } \mathrm{i} \text { hari } \\
& \text { ke } \mathrm{t} \text { saham masing-masing } \\
\mathrm{P}_{\mathrm{it}}{ }^{-1}= & \begin{array}{l}
\text { Harga } \\
\text { perusahaan pada hari ke } \mathrm{t}-1
\end{array}
\end{aligned}
$$

2) Menghitung Return pasar harian selama periode pengamatan dengan rumus:

$$
\mathrm{R}_{\mathrm{mt}}=\frac{\mathrm{IHSG}_{\mathrm{it}}-\mathrm{IHSG}_{\mathrm{it}-1}}{\mathrm{IHSG}_{\mathrm{it}-1}}
$$

Di mana:

$\mathrm{R}_{\mathrm{mt}} \quad=$ Return pasar harian pada hari $\mathrm{t}$

$\mathrm{IHSG}_{1}=$ Indeks Harga Saham Gabungan pada hari t

$\mathrm{IHSG}_{\mathrm{t}-1}=$ Indeks Harga Saham Gabungan pada hari t-1

3) Menghitung $\alpha$ dan $\beta$ untuk tiap-tiap saham dengan meregresikan return harian saham terhadap market return harian selama periode estimasi. Beta pasar untuk pasar modal yang perdagangannya tidak sinkron harus disesuaikan karena beta tersebut menggandung bias maka harus disesuaikan. Adapun koreksi beta yang digunakan dengan periode koreksi yang cukup panjang yaitu empat periode mundur (lag) dan empat periode maju (lead). Metode ini digunakan karena 
dianggap paling mampu mengoreksi bias terutama untuk data return yang tidak berdistribusi normal.

4) Menghitung abnormal return tiap saham selama periode peristiwa dengan rumus:

$A R_{i, t}=R_{i, t}-E\left(R_{i, t}\right)$

Di mana:

$\mathrm{R}_{\mathrm{i}, \mathrm{t}} \quad=$ Actual return saham i pada hari $\mathrm{t}$

$\mathrm{E}\left(\mathrm{R}_{\mathrm{i}, \mathrm{t}}\right)=$ Expected return saham $\mathrm{i}$ pada hari t

5) Menghitung Average Abnormal Return setiap hari selama periode peristiwa:

$\mathrm{AAR}_{\mathrm{t}}=\Sigma \mathrm{AR}_{\mathrm{it}} / \mathrm{k}$

Di mana:

$\mathrm{AAR}_{\mathrm{t}}=$ Rata-rata abnormal return pada hari ke-t

$\mathrm{ARi}, \mathrm{t}=$ Abnormal return saham $\mathrm{i}$ pada hari $\mathrm{t}$

$\mathrm{k}$ = Jumlah saham yang terpengaruh oleh pengumuman

6) Melakukan pengujian statistik (t-test) terhadap average abnormal return (AAR) pada periode peristiwa untuk melihat signifikansi AAR tersebut. SAAR1.t (Standardized Average Abnormal Return) merupakan nilai hitung untuk AAR pada hari ke-t selama periode peristiwa (Jogiyanto, 2003).

a). Menghitung KSE dengan rumus:

$\mathrm{KSE}_{\mathrm{i}}=\sqrt{\frac{\sum\left(\mathrm{R}_{\mathrm{i}, \mathrm{t}}-\mathrm{E}\left(\mathrm{R}_{\mathrm{i}, \mathrm{t}}\right)\right)^{2}}{\mathrm{~T}-2}}$

Keterangan:

$\mathrm{KSE}_{\mathrm{i}}=$ Kesalahan Standar Estimasi saham i

$\mathrm{R}_{\mathrm{i}, \mathrm{t}} \quad=$ Actual return saham $\mathrm{i}$

$\mathrm{E}\left(\mathrm{R}_{\mathrm{i}, \mathrm{t}}\right)=$ Expected return saham $\mathrm{i}$

$\mathrm{T}-2$ = Jumlah hari di periode estimasi b). Menentukan Standardized Average Abnormal Return $(\mathrm{SAAR}=\mathrm{t}-$ hitung) selama periode peristiwa dan dianggap sebagai t-hitung untuk AAR dengan rumus:

$$
\text { SAAR }_{\mathrm{t}}=\frac{1}{\sqrt{\mathrm{k}}} \sum \frac{\mathrm{AR}_{\mathrm{it}}}{\mathrm{KSE}_{\mathrm{it}}}
$$

Di mana:

$\mathrm{SAAR}_{\mathrm{t}}=$ Standardized Average Abnormal Return saham pada hari $\mathrm{t}$ di periode peristiwa

$\mathrm{AR}_{\mathrm{it}}=$ Abnormal Return saham i pada hari $\mathrm{t}$

$\mathrm{KSE}_{\mathrm{it}}=$ Kesalahan Standar Estimasi saham i pada hari ke $\mathrm{t}$ di periode peristiwa.

7) Menghitung Cumulative Abnormal Return (CAR) yang merupakan penjumlahan abnormal return mulai hari awal periode jendela sampai hari ke-t: CARi,t $=\Sigma$ ARi, $\mathrm{t}$

8) Menghitung Cumulative Average Abnormal Return (CAARt) selama peride peristiwa ( $t-10$ sampai $t+10)$.

$\mathrm{CAAR}_{\mathrm{i}, \mathrm{t}}=\Sigma \mathrm{AAR}_{\mathrm{t}}$

Keterangan:

$\mathrm{CAAR}_{\mathrm{i}, \mathrm{t}}=$ Cumulative Average Abnormal Return saham $\mathrm{i}$ hari ke $\mathrm{t}$

$\mathrm{AAR}_{\mathrm{t}}=$ Average Abnormal Return saham i hari ke $\mathrm{t}$

$\mathrm{t}=$ Hari pada periode peristiwa

\section{HASIL ANALISIS DAN PEMBAHASAN}

Pengujian hipotesis pertama yang menggunakan metode event study dilakukan pada masing-masing perusahaan sampel untuk peristiwa inisiasi dan omisi dividen. Pengujian signifikasi tersebut dilakukan dengan menggunakan uji one sample t-test. Sedangkan pengujian hipotesis kedua juga menggunakan metode event study. Terlebih dahulu dihitung abnormal retun 
menggunakan single factor market model untuk melihat apakah tingkat abnormal return signifikan atau tidak.

\section{Analisis Deskriptif terhadap Dividend Initiatons}

Setelah dilakukan perhitungan seluruh data penelitian seperti langkahlangkah di atas, selanjutnya dapat digambarkan tentang abnormal return pada periode peristiwa. Abnormal return adalah selisih antara return yang sesungguhnya terjadi dengan return ekspektasi. Abnormal return merupakan reaksi harga terhadap pengumuman dividen pada suatu hari tertentu. Hasil deskriptif tentang reaksi pasar atas harga saham di sekitar hari pengumuman dapat ditunjukkan pada Tabel 1 berikut:

Tabel 1: AAR Kelompok Saham dengan dividend initiation tahun 2004 - 2008

\begin{tabular}{|c|c|c|c|}
\hline Periode & $\mathrm{N}$ & AR & CAAR \\
\hline AR t-10 & 37 & -0.0010 & $0 . \theta 010$ \\
\hline AR t-9 & 37 & 0.0026 & 0.0016 \\
\hline AR t-8 & 37 & 0.0025 & 0.0040 \\
\hline AR t-7 & 37 & 0.0030 & 0.0071 \\
\hline AR t-6 & 37 & 0.0038 & 0.0108 \\
\hline AR t-5 & 37 & 0.0148 & 0.0256 \\
\hline AR t-4 & 37 & -0.0034 & 0.0222 \\
\hline AR t-3 & 37 & -0.0137 & 0.0085 \\
\hline AR t-2 & 37 & -0.0135 & -0.0049 \\
\hline AR t-1 & 37 & -0.0039 & -0.0089 \\
\hline AR t-0 & 37 & -0.0031 & -0.0120 \\
\hline AR $t+1$ & 37 & 0.0104 & -0.0016 \\
\hline $\mathrm{AR} t+2$ & 37 & 0.0071 & 0.0055 \\
\hline$A R t+3$ & 37 & -0.0060 & -0.0005 \\
\hline $\mathrm{AR} t+4$ & 37 & 0.0152 & 0.0147 \\
\hline AR $t+5$ & 37 & 0.0308 & 0.0455 \\
\hline$A R t+6$ & 37 & 0.0037 & 0.0492 \\
\hline $\mathrm{AR} \mathrm{t}+7$ & 37 & 0.0093 & 0.0585 \\
\hline AR $t+8$ & 37 & 0.0055 & 0.0640 \\
\hline AR t+9 & 37 & -0.0024 & 0.0616 \\
\hline $\mathrm{AR} t+10$ & 37 & 0.0028 & 0.0644 \\
\hline
\end{tabular}

Sumber: Data sekunder diolah, 2009 
Berdasarkan deskriptif terhadap $a b$ normal return menunjukkan bahwa sebagian besarnya abnormal return periode sebelum pengumuman dividen inisiasi bernilai negatif. Keadaan ini mengindikasikan bahwa selama periode penelitian sebelum pengumuman dividen pasar cenderung memberikan reaksi yang negatif. Hal ini disebabkan karena informasi akan pengumuman dividend initiation, belum dapat dipastikan akan memberikan kemakmuran bagi investor yang berupa keuntungan dalam bentuk tunai yaitu pembayaran dividen. Namun demikian setelah terdapat kepastian akan pembayaran dividen, yaitu pada periode setelah pengumuman abnormal return mengalami peningkatan dan puncaknya (tertinggi) pada $t+5$. Walaupun pembayaran dividen belum dilaksanakan pada saat pengumuman tersebut, biasanya dibayarkan kurang lebih satu bulan kemudian, namun investor telah mendapatkan kepastian bahwa dirinya akan memperoleh keuntungan dalam bentuk dividen tunai. Informasi yang baik ini langsung disambut dengan adanya reaksi pasar yang meningkat sehingga harga saham mengalami peningkatan. Peningkatan harga saham juga terjadi akibat aksi borong oleh investor lain untuk membeli saham-saham yang konsisten melakukan pembayaran dividen. Keadaan ini menimbulkan spekulasi bagi pelaku pasar saham lainnya untuk memanfaatkan keuntungan lewat capital gain dengan aksi profit taking yaitu dengan cara menjual saham-saham disaat harga mengalami nilai puncak (tertinggi). Hal ini dapat ditunjukkan dengan adanya penurunan abnormal return pada $\mathrm{t}+3$ dan $\mathrm{t}+9$ dengan abnormal return negatif yang disebabkan nilai Abnormal Return telah mencapai nilai yang cukup tinggi pada periode sebelumnya. Penurunan abnormal return tersebut karena adanya penyesuaian harga saham (equilibrium) dimana harga kembali menurun disaat harga berada diatas harga normal pada periode sebelumnya. Hal ini wajar karena fluktuasi harga saham di Bursa Efek Jakarta, sangat dipengaruhi oleh penawaran dan permintaan harga saham. Jika investor tidak hati-hati dalam melakukan investasi di BEJ, kondisi ini dapat menimbulkan kerugian, bahkan banyak pelaku pasar yang mengalami kebangkrutan yang serius karena investor kurang jeli atau belum berpengalaman dalam melakukan investasi di Bursa Efek Jakarta. Hasil ini dapat dilihat seperti gambar berikut:

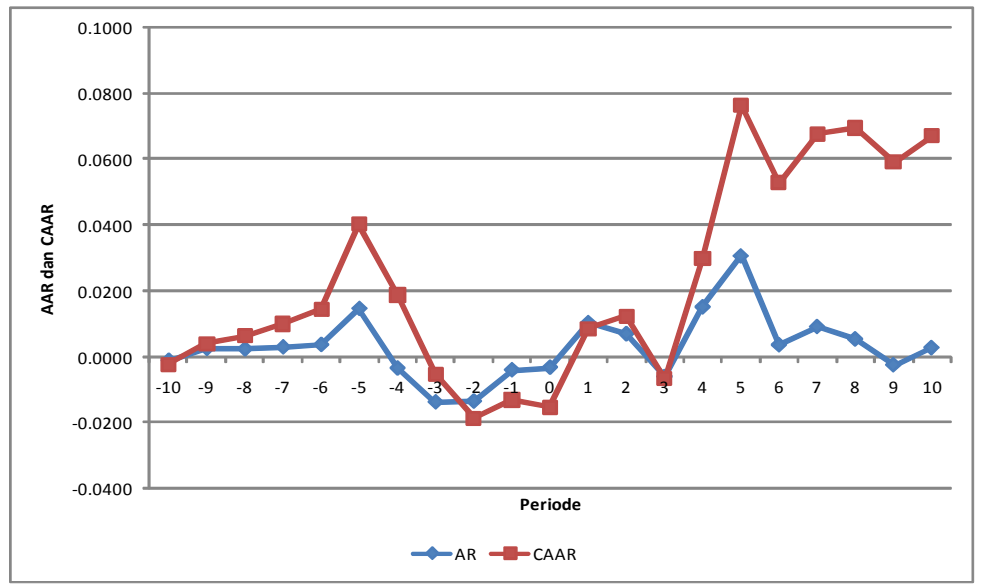

Gambar 2: Grafik AAR kelompok perusahaan yang mengumumkan dividend initiation 
Gambar 2 di atas menunjukkan bahwa grafik pergerakan Abnormal Return mulai meningkat sejak periode $\mathrm{t}-10$ hingga t5. Namun pada t-4 AR kembali menurun hingga bernilai negatif, meningkat pada $\mathrm{t}-2$ dan kembali meningkat pada $\mathrm{t}-1$ hingga $\mathrm{t}+1$. Pergerakan abnormal return meningkat cukup tajam hingga nilai tertinggi pada $\mathrm{t}+5$. Selanjutnya abnormal return kembali menurun hingga mencapai nilai negatif pada t+9 dan meningkat kembali pada $\mathrm{t}+10$. Penurunan dan peningkatan abnormal return ini disebabkan karena adanya penyesuaian harga saham. Jika dilihat dari cummulative abnormal return juga terlihat grafik yang terus meningkat selama periode penelitian, yang menunjukkan bahwa pasar secara kumulatif bereaksi positif, yang menyebabkan harga saham terus mengalami pening- katan di sekitar pengumuman dividend initiation.

\section{Analisis Deskriptif terhadap Dividend Omission}

Dari 13 kasus yang termasuk dalam kelompok dividend omission, yaitu perusahaan yang menghapus pembayaran dividen, yang sebelumnya telah membayar dividen selama 2 tahun berturut-turut, telah memberikan reaksi pasar atas harga saham terhadap pengumuman dividend omission tersebut seperti terlihat pada Tabel 2.

Hasil perhitungan pada tersebut menunjukkan bahwa reaksi pasar pada perusahaan yang melakukan pembagian dividend ommission cukup berfluktuatif. Hal ini dapat dilihat dengan pergerakan Abnormal return seperti pada gambar 2.

Tabel 2: Besarnya AAR dan CAAR Kelompok Saham dengan dividend ommission tahun $2004-2008$

\begin{tabular}{cccc}
\hline Periode & $\mathrm{N}$ & AR & CAAR \\
\hline AR t-10 & 13 & -0.0400 & -0.0400 \\
AR t-9 & 13 & -0.0390 & -0.0790 \\
AR t-8 & 13 & 0.0356 & -0.0433 \\
AR t-7 & 13 & 0.0125 & -0.0309 \\
AR t-6 & 13 & 0.0030 & -0.0279 \\
AR t-5 & 13 & -0.0205 & -0.0483 \\
AR t-4 & 13 & 0.0056 & -0.0427 \\
AR t-3 & 13 & -0.0166 & -0.0593 \\
AR t-2 & 13 & -0.0054 & -0.0647 \\
AR t-1 & 13 & -0.0235 & -0.0882 \\
AR t-0 & 13 & 0.0031 & -0.0851 \\
AR t+1 & 13 & -0.0111 & -0.0962 \\
AR t+2 & -0.0118 & -0.1081 \\
AR t+3 & 13 & -0.0118 & -0.1198 \\
AR t+4 & 13 & -0.0001 & -0.1200 \\
AR t+5 & 13 & 0.0024 & -0.1175 \\
AR t+6 & 13 & -0.0039 & -0.1214 \\
AR t+7 & 13 & -0.0511 & -0.1725 \\
AR t+8 & 13 & 0.0672 & -0.1053 \\
AR t+9 & 13 & 0.0269 & -0.0784 \\
AR t+10 & 13 & -0.0589 & -0.1373 \\
\hline
\end{tabular}

Sumber: Data sekunder, diolah 2009 


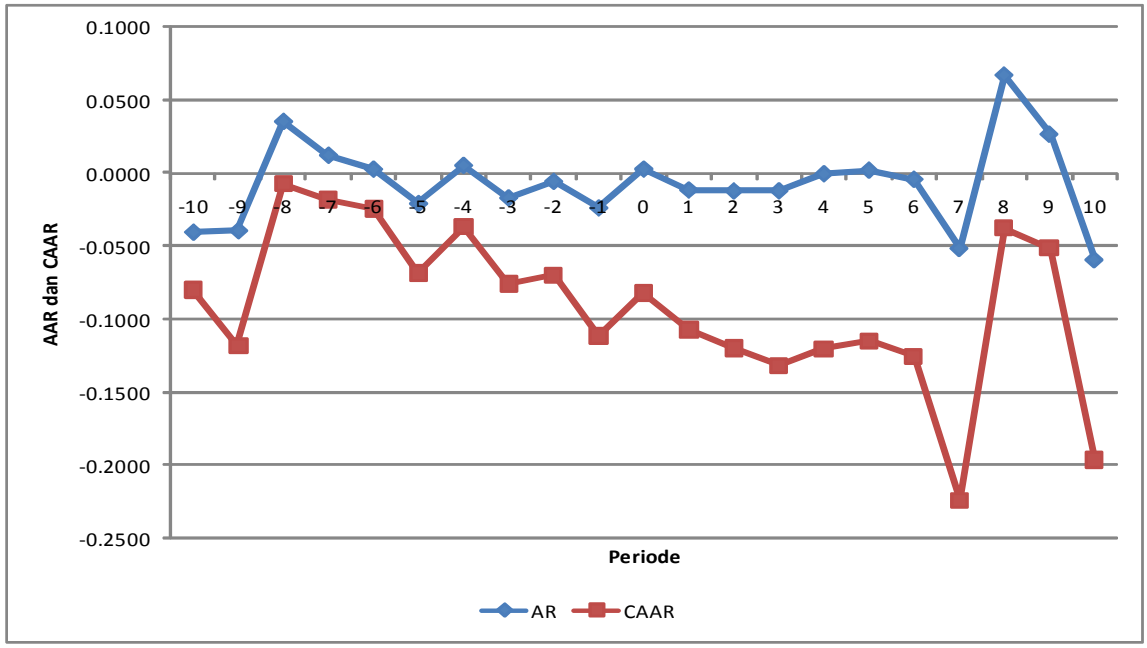

Gambar 2: Grafik AAR kelompok saham dengan dividend ommission

Berdasarkan Gambar 2 di atas terlihat bahwa pergerakan abnormal return cenderung berfluktuatif, mengikuti pola pasar. Abnormal return mulai terlihat menurun sejak $\mathrm{t}-8$ hingga $\mathrm{t}-5$, namun bergerak meningkat hingga $\mathrm{t}-4$, menurun pada $\mathrm{t}-3$, meningkat lagi pada $\mathrm{t}-2$, dan seterusnya fluktuasi ini terjadi hingga $t+10$. Namun Bahkan jika dilihat dari pergerakan Cummulative Abnormal Return menunjukkan bahwa grafik cukup berfluktuasi, sehingga mencapai nilai negatif pada seluruh periode pengamatan.

\section{Hasil Uji Hipotesis Pertama}

Hipotesis pertama dalam penelitian ini menyatakan bahwa "Terdapat abnormal return positif pada hari pengumuman inisiasi dividen”. Dalam pengujian ini digunakan one sample $t$ - test. Hasil one sample t- test ditunjukkan pada tabel 3 .

Berdasarkan hasil pengujian t-test dengan one sample t-test, menunjukkan bahwa untuk hari $\mathrm{t}-5, \mathrm{t}+1, \mathrm{t}+2, \mathrm{t}+4$ dan $\mathrm{t}+7$ terbukti abnormal return bernilai positif dan signifikan dengan probabilitas masingmasing sebesar $0,047<0,05 ; 0,011<0,05$; $0,018<0,05 ; 0,002<0,05$ dan $0,010<0,05$. Sedangkan untuk hari-hari yang lain yaitu t3 dan $t+3$ terjadi reaksi negatif signifikan dan sisanya tidak terjadi abnormal return yang signifikan. Dengan demikian hipotesis pertama yang menyatakan "Adanya reaksi pasar yang positif terhadap pengumuman dividend initiation" dapat didukung. 
Jurnal Siasat Bisnis Vol. 13 No. 2, Agustus 2009 Hal: 113-128

Tabel 3: Hasil Uji One Sample t test pada dividend initiation tahun 2004-2008

\begin{tabular}{cccc}
\hline Periode & $\mathrm{T}$ & Sig. (2-tailed) & Sig. (1-tailed) \\
\hline AR t-10 & -0.296 & 0.769 & 0.385 \\
AR t-9 & 1.017 & 0.316 & 0.158 \\
AR t-8 & 0.843 & 0.405 & 0.202 \\
AR t-7 & 0.787 & 0.436 & 0.218 \\
AR t-6 & 0.338 & 0.737 & 0.369 \\
AR t-5 & $\mathbf{1 . 7 1 7}$ & $\mathbf{0 . 0 9 5}$ & $\mathbf{0 . 0 4 7}$ \\
AR t-4 & -0.225 & 0.823 & 0.411 \\
AR t-3 & -2.031 & 0.050 & 0.025 \\
AR t-2 & -1.644 & 0.109 & 0.054 \\
AR t-1 & -0.830 & 0.412 & 0.206 \\
AR t-0 & -0.778 & 0.441 & 0.221 \\
AR t+1 & $\mathbf{2 . 3 8 9}$ & $\mathbf{0 . 0 2 2}$ & $\mathbf{0 . 0 1 1} *$ \\
AR t+2 & $\mathbf{2 . 1 6 8}$ & $\mathbf{0 . 0 3 7}$ & $\mathbf{0 . 0 1 8 *}$ \\
AR t+3 & -1.899 & 0.066 & 0.033 \\
AR t+4 & $\mathbf{3 . 1 7 8}$ & $\mathbf{0 . 0 0 3}$ & $\mathbf{0 . 0 0 2 *}$ \\
AR t+5 & 1.122 & 0.269 & 0.135 \\
AR t+6 & 1.519 & 0.137 & 0.069 \\
AR t+7 & $\mathbf{2 . 4 4 4}$ & $\mathbf{0 . 0 2 0}$ & $\mathbf{0 . 0 1 0}$ \\
AR t+8 & 1.616 & 0.115 & 0.057 \\
AR t+9 & -0.633 & 0.531 & 0.265 \\
AR t+10 & 1.110 & 0.274 & 0.137 \\
\hline
\end{tabular}

Keterangan :

Sig-1 tailed diperoleh dari $0,5 *$ Sig-2 tailed

* : Signifikan positif pada level $5 \%$ dengan pengujian 1 sisi

Sumber : Data sekunder, diolah 2010

\section{Hasil Uji Hipotesis Kedua}

Hipotesis kedua dalam penelitian ini menyatakan bahwa "Adanya reaksi pasar yang negatif terhadap pengumuman dividend omission" Dalam pengujian ini digunakan one sample t- test. Hasil one sample t- test ditunjukkan pada tabel 4.

Berdasarkan hasil pengujian t-test dengan one sample t-test, menunjukkan bahwa untuk hari $\mathrm{t}-9$ dan $\mathrm{t}+1$ terbukti abnormal return bernilai negatif dan signifikan dengan probabilitas masingmasing sebesar 0,036<0,05; dan 0,046<0,05. Sedangkan untuk hari-hari yang lain tidak terjadi abnormal return yang signifikan. Dari hasil perhitungan diatas menunjukkan bahwa pasar bereaksi signifikan negatif terhadap pengumuman dividen omisi. Hal ini berarti pengumuman dividen omisi tersebut mengundang sinyal negatif atas prospek perusahaan di masa datang, karena pihak manajer dianggap tidak mampu mengelola earning bagi kepentingan pemegang saham jangka panjang. Dengan demikian hipotesis kedua dalam penelitian ini yang menyatakan "Adanya reaksi pasar yang negatif terhadap pengumuman dividend ommission" dapat diterima. 
Tabel 4: Uji One Sampel t test Pada perusahaan dividend ommission tahun $2004-2008$

\begin{tabular}{cccc}
\hline Periode & $\mathrm{t}$ & Sig. (2-tailed) & Sig. (1-tailed) \\
\hline AR t-10 & -0.905 & 0.383 & 0.192 \\
AR t-9 & $\mathbf{- 1 . 9 7 8}$ & $\mathbf{0 . 0 7 1}$ & $\mathbf{0 . 0 3 6 *}$ \\
AR t-8 & 0.893 & 0.389 & 0.195 \\
AR t-7 & 0.879 & 0.397 & 0.198 \\
AR t-6 & 0.511 & 0.619 & 0.309 \\
AR t-5 & -1.019 & 0.328 & 0.164 \\
AR t-4 & 0.733 & 0.478 & 0.239 \\
AR t-3 & -0.913 & 0.379 & 0.190 \\
AR t-2 & -0.796 & 0.441 & 0.221 \\
AR t-1 & -1.043 & 0.318 & 0.159 \\
AR t-0 & 0.525 & 0.609 & 0.305 \\
AR t $+\mathbf{1}$ & $\mathbf{- 1 . 8 2 5}$ & $\mathbf{0 . 0 9 3}$ & $\mathbf{0 . 0 4 6}$ \\
AR t+2 & -1.128 & 0.281 & 0.141 \\
AR t+3 & -0.690 & 0.503 & 0.252 \\
AR t+4 & -0.014 & 0.989 & 0.494 \\
AR t+5 & 0.159 & 0.876 & 0.438 \\
AR t+6 & -0.553 & 0.590 & 0.295 \\
AR t+7 & -1.144 & 0.275 & 0.138 \\
AR t+8 & 1.055 & 0.312 & 0.156 \\
AR t+9 & 1.120 & 0.285 & 0.142 \\
AR t +10 & -1.070 & 0.306 & 0.153 \\
\hline
\end{tabular}

Keterangan:

Sig-1 tailed diperoleh dari $0,5 *$ Sig-2 tailed

* : Signifikan negatif pada level 5\% dengan pengujian 1 sisi

Sumber: Data sekunder, diolah 2010

\section{Pembahasan Hasil Penelitian}

Hasil analisis pada pengujian pengumuman dividen pengaruhnya terhadap abnormal return menunjukkan adanya pengaruh yang signifikan. Hal ini dapat dibuktikan dengan hasil uji $\mathrm{t}$ dengan probabilitas dibawah 0,05 . Pengaruh yang signifikan terjadi pada pengumuman dividend initiation dengan pengaruh positif signifikan, sedangkan untuk pengumuman dividend ommission terdapat reaksi pasar negatif signifikan. Artinya pengumuman dividend initiation mempunyai sinyal atau kandungan informasi tertentu yang menyebabkan pasar bereaksi lebih dari keadaan normal terhadap informasi tersebut, sementara pengumuman dividend ommission mempengaruhi investor untuk melepas saham-sahamnya sehingga harga saham bergerak menurun atau terjadi Abnormal Return yang signifikan.

Hasil penelitian ini mendukung hasil penelitian yang dilakukan oleh Sri Dwi Ambarwati (2005) yang menemukan bahwa pasar bereaksi positif terhadap inisiasi dividen dan pasar bereaksi negatif terhadap omisi dividen. Begitu juga dengan hasil penelitian yang dilakukan oleh Mulyati (2003) yang menemukan bahwa reaksi saham positif terhadap kenaikan dividen yang dibayarkan pada hari ke 5 sebelum pengumuman dan reaksi saham negatif terhadap penurunan dividen yang dibayarkan pada hari ke 5 setelah pengumuman dividen. 
Hasil penelitian ini membuktikan bahwa pengumuman dividend initiation berpengaruh terhadap Abnormal Return. Secara teoritis informasi dari pengumuman dividend initiation merupakan unsur penting bagi investor dan pelaku bisnis karena informasi pada hakekatnya menyajikan keterangan, catatan atau gambaran, baik untuk keadaan masa lalu, saat ini, maupun keadaan masa yang akan datang bagi kelangsungan suatu perusahaan. Informasi merupakan faktor yang memberikan arti penting bagi investor, khususnya dalam hal untuk pengambilan keputusan. Sehingga pada setelah pengumuman dividend initiation terjadi peningkatan permintaan terhadap saham saham, hal ini terjadi karena investor menilai bahwa perusahaan yang mengeluarkan pengumuman dividend initiation dapat dipastikan memiliki prospek yang cerah dimasa yang akan datang. Apabila kita hubungkan dengan efisiensi pasar maka disini disimpulkan pasar bereaksi efisien secara informasi karena ditemukan nilai Abnormal Return yang positif signifikan sebagai dampak adanya pengumuman dividen yang meningkat.

Sedangkan pengumuman dividend ommission, memberikan pengaruh secara signifikan negatif terhadap Abnormal Return. Hal ini menunjukkan bahwa penghapusan pembayaran dividen umumnya investor menganggap prospek perusahaan di masa depan kurang bagus, sehingga tidak mampu membayar atau menghapus dividen pertama kalinya. Reaksi negatif timbul karena pengumuman dividen tersebut mengundang sinyal negatif atas prospek pengembangan perusahaan di masa datang, karena pihak manajer dianggap tidak mampu mengelola earning bagi kepentingan pemegang saham jangka panjang

Teori yang relevan dengan hasil penelitian ini adalah teori Dividend Relevant Theory yang menyatakan bahwa pemegang saham menyukai pembagian dividen. Apa- bila perusahaan selalu dapat memberikan dividen kepada para pemegang sahamnya maka investor akan menilai baik kinerja perusahaan tersebut. Dengan demikian akan menarik para investor untuk menanamkan modalnya pada perusahaan yang bersangkutan. Hal tersebut pada akhirnya akan dapat membuat harga saham naik. Begitu juga hasil penelitian ini telah relevan dengan Theory Signaling Hypothesis. Jika pada teori kebijaksanaan dividen tidak relevan menyatakan bahwa baik investor maupun manajer memiliki penilaian yang sama terhadap perusahaan, akan tetapi kenyataannya manajer cenderung memiliki informasi yang lebih baik tentang prospek perusahaan dibandingkan dengan investor. Akibatnya investor menilai bahwa capital gain lebih beresiko dibandingkan dengan dividen. Sedangkan teori kebijaksanaan ini menyatakan bahwa pengumuman dividen merupakan suatu sinyal bagi investor bahwa manajemen perusahaan meramalkan suatu penghasilan yang lebih baik.

\section{PENUTUP}

Berdasarkan hasil analisis data dan pembahasan maka dapat ditarik kesimpulan sebagai berikut:

1) Terdapat reaksi pasar positif dan signifikan diseputar pengumuman dividend initiation. Hal ini berarti pengumuman dividend initiation berpengaruh secara signifikan terhadap Abnormal Return, sehingga pengumuman tersebut direspon oleh investor sebagai informasi yang baik sehingga harga saham mengalami peningkatan yang berarti.

2) Terdapat reaksi pasar negatif dan signifikan diseputar pengumuman dividend ommission. Hal ini berarti terdapat pengaruh yang signifikan negatif pengumuman dividend ommission terhadap Abnormal Return, yang menyebabkan investor merespon buruk sehingga harga saham mengalami penurunan. 
Adapun implikasi hasil dari pembahasan penelitian ini meliputi:

1) Berdasarkan kesimpulan diatas, perusahaan-perusahaan go public sebaiknya mengantisipasi keadaan di pasar sebelum peristiwa pengumuman dividen, yaitu dengan cara mengasosiasikan pengumuman dividen merupakan sinyal yang informatif kepada investor mengenai prospek perusahaan yang bagus dimasa yang akan datang. Hal ini akan mendorong para investor mempunyai anggapan yang positif atas pengumuman dividen sehingga harga saham akan mengalami peningkatan setelah adanya pengumuman tersebut.

2) Bagi investor sebaiknya menanamkan investasinya untuk jangka panjang lebih memilih saham kelompok dividend initiation, hal ini disebabkan saham yang mempunyai dividend initiation cenderung memperoleh return tidak normal yang positif, sedangkan untuk tujuan jangka pendek sebaiknya menanamkan investasinya pada perusahaan kelompok dividend ommission, dimana keuntungan yang diperoleh hanya mengandalkan capital gain, yaitu dengan membeli harga saham pada saat terendah, tanpa menahan lama jika telah terjadi peningkatan harga dilakukan aksi jual.

3) Peneliti menyadari bahwa penelitian ini masih jauh dari sempurna. Untuk itu peneliti memberikan saran untuk penelitian lanjutan yaitu dapat melakukan pengujian tidak hanya pada pengumuman dividend initiation dan dividend ommission tetapi diasosiasikan dengan perusahaan yang membagikan secara meningkat, menurun atau tetap. Hal ini penting karena akan diketahui lebih jelas strategi yang paling baik bagi perusahaan apakah membagikan dividen secara meningkat, menurun atau dengan jumlah yang tetap.

\section{DAFTAR PUSTAKA}

Ambarwati, S.D.A. (2005). Pengaruh Dividend Initiations Dan Dividend Cut/Omissions Terhadap Return Saham Di Bursa Efek Jakarta. Jurnal Siasat Bisnis, 1 (10): 73-93.

Asquith dan Mullins. (1983). The Impact of Initiations Dividend Payment on Shareholder Wealth. Journal of Business, 259-270.

Caecilia. (2002). Analisis Reaksi Pemegang Saham terhadap Dividend Omissions/Cut di BEJ. Tesis $S-2$ $U G M$

Dewantoro. (2005). Analisis Kandungan Informasi Dividend an Ketepatan Reaksi Pasar Pengujian terhadap Signaling Theory Studi Empiris di BEJ. Tesis $S$-2 UGM.

Gosh dan Woolridge. (1988). (dalam Caecillia, 2002). An Analysis of Shareholder Reaction to Dividend Cut and Omissions, 281-294.

Healy and Palepu. (1988). Earning Informations Conveyed by Dividend Initiations and Omissions, Journal of Financial Economics, 149-175.

Husnan, S. (2005). Dasar-Dasar Teori Portofolio dan Analisis Sekuritas. Edisiketiga dan keempat. Yogyakarta: UPP AMP YKPN.

Jogiyanto, H.M. (2003). Teori Portofolio dan Analisis Investasi. Edisi Ketiga dan Kelima. Yogyakarta: BPFE.

Kartini. (2001). Analisis Reaksi Pemegang saham Terhadap pengumuman Perubahan Dividen di Bursa Efek Jakarta. 
Martono dan Harjito, D. A. (2007) Manajemen Keuangan. Edisi Keenam, Ekonisia, Yogyakarta.

Modigliani and Miller. (1961). Dividend Policy, Growth and The Valuation of Shares. Journal of Business, 411-433.

Mulyati, S. (2003). Reaksi Harga Saham Terhadap Pengumuman Perubahan Pembayaran Dividen Yield di Bursa Efek Jakarta. Jurnal Siasat Bisnis, No.8 Vol 2, Hal 233-249.
Puspitasari dan Witono. (2004). Pengaruh pengumuman Dividen Tunai ditinjau dari Kenaikan dan Penurunan Dividen Terhadap Variabilitas tingkat Keuntungan saham di Bursa Efek Jakarta. Jurnal akuntansi dan keuangan, Hal 107-126.

Setyowuri. (2005). Pengujian Efisiensi Pasar Bentuk Setengah Kuat Secara Informasi Terhadap Pengumuman inisiasi Dividend an Omisi Dividen. (tidak dipublikasikan). Yogyakarta. MM UGM. 